DOI: https://doi.org/10.31874/2309-1606-2021-27-1-5

УДК $316.012: 141.7$

\title{
Алла Макарова
}

\section{Архетипний характер освітньої діяльності особистості: соціально- філософський аналіз}

У статті проаналізовано проблеми сучасної освітньої діяльності в контексті соціально-

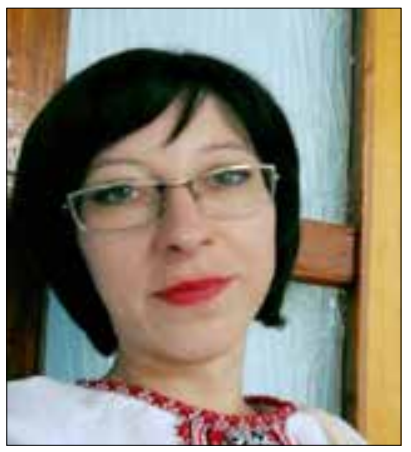
філософського аналізу особливостей специфіки інформаційного суспільства. Розглянуто проблеми «саморозвитку» та «самопрезентації» особистості у специфіці їх трактування в умовах сучасної ситуації соціальної транзитивності. Як проблемну охарактеризовано позицію усунення інститутів освіти з освітніх процесів, що становить загрозу створення явища освіти без належної педагогічної складової. Порівнюються «традиційні» $i$ «інноваційні» акценти в соціально-філософському дискурсі освіти, наводяться їх смислові конотації. Обгрунтовано необхідність дотримання балансу архетипно-освітньої функціональності, яка полягає у формуванні через комплекс освітніх рівнів системи соціалізаційних дій, що мають виражений особливими функціями архетипний зміст. Науковою новизною дослідження є схематичне зіставлення функціональних характеристик архетипу із завданнями різних рівнів освіти як орієнтації на різні потенції особистості. Зокрема, співставлені соціальні функції архетипів (в трикомпонентній авторській концепції), архетипна типологія і схематика Еріка Берна, Карла-Густава Юнга та Маргарет Марк і Керол Пірсон із завданнями і смислами рівнів освіти (початкова, середня і середня спеціальна, вища). Виділено три функції освіти, детерміновані архетипними змістами педагогічної діяльності. При цьому запропонована схема, в якій орієнтувально-координаційна, стереотипізуюче-нормативна та інтегративно-систематизаційна архетипні складові формують завдання і функції освіти: кореляційну, корекційну і компенсаційну. Метою статті є виявлення стійких функцій, принципів, елементів, які при будь-якому реформуванні освітньої сфери, зокрема, педагогічної, повинні бути збережені, оскільки становлять смислові основи ї̈ існування як соціального інституту розвитку особистості. Такими визнаються єдність навчання і виховання, єдність минулого, теперішнього і майбутнього як органічних ланок передачі соціального досвіду і збереження соціальної пам'яті. Відповідно виділені шість архетипів освітньої діяльності.

Ключові слова: архетип, освітня діяльність особистості, соціально-філософський аналіз, інформаційне суспільство, соціальна роль.

(C) А. Макарова, 2021 


\section{Передмова}

Безперечно, що у русі, в розвитку знаходяться у XXI столітті соціальні інститути інформаційного суспільства - але чи знаходиться у розвитку особистість, як змістовний споживач пропозицій соціальних інститутів, i в чому полягає користь для цього споживача від існування інституту освіти, якщо трактування освіти полягатиме лише у здобутті чітко форматованої у межах задокументованих навчальних ресурсів інформації з мінімізацією ролі самих освітян? Ці питання постають зараз перед освітньою спільнотою. Але ця проблема «коректного реформування» виходить за межі окреслення специфічних освітніх траєкторій, оскільки розгортається в контексті і у просторі соціокультурної діяльності, що стрімко трансформується. Розмислам над цією проблемою тому необхідно надати соціально-філософського характеру, щоб схематична траєкторія могла перетворитися на вектор розвитку, до якого прикладені творчі сутнісні сили (дух, душа, розум). Саме їх консолідація дозволяє людству пережити зміну епох, зберігши власну сутність, основу, що виділяє людину з природного світу і відділяє від біологічної детермінованості життєвих процесів. Перш, ніж реформувати технології освіти, потрібно згадати про філософію освіти і заново визначити їі засобами ідейні основи освітньої діяльності, їі екзистенційні, а не інформаційні завдання. Адже останні стосовно внутрішніх сенсів людини є їі формальними, зовнішніми, похідними параметрами - індуктивними, а не дедуктивними смисловими величинами.

Метою статті $€$ виявлення функцій, принципів, елементів, які при будь-якому реформуванні освітня сфера, зокрема, педагогічна, в жодному разі не повинна втрачати, іншими словами - які повинні бути збереженими при будь-якій системі освіти, адже становлять смислові підвалини самого ії існування як соціального інституту розвитку особистості. Дане завдання можливо було б реалізувати у площині використання методів історії педагогіки - простежуючи генетично історичну трансформацію понять освіти; методами соціологічного контент-аналізу, виявивши у масиві текстів педагогічної тематики константні вирази; зрештою, методами епістемологічного аналізу, з'ясувавши структурно-змістовну кореляцію ідей, закладених у базових поняттях. Всі ці методи виявили б, на нашу думку, базові функції освітньої діяльності в контексті їі основного соціального завдання: формування соціально свідомої особистості. Нам наразі видається цікавим і змістовним вирішення цього завдання методом компаративного та функціонального аналізу в межах архетипного підходу, який останнім часом набув популярності у колах дослідників соціогуманітарних явищ. Соціально-філософський аналіз специфіки архетипного підходу здійснили Е. Афонін, 
О. Донченко, В. Зелюк, С. Маленко, В. Менжулін, А. Некита, Т. Новаченко, Т. Плахтій, О. Радченко, О. Сушій. Цінну основу для роздумів являють праці молодих вчених - Н. Москалець, В. Омельяненка, Ю. Черкасової, О. Шумейко, С. Яцика та ще багатьох дослідників. У поєднаннями із соціально-педагогічними рефлексіями В. Андрущенка, В. Беха, Є. Голобородька, Д. Максименка, М. Міщенко, І. Лях, Л. Рибалко, Л. Романкової, Г. Швалба, 3. Юрченко ця специфіка постає особливо актуальною. Дослідження функціонального співвідношення специфіки архетипу та освітньої діяльності $\epsilon$ науковою новизною даної статті.

\section{Характеристика стану сучасної освіти і соціально-філософська рефлексія над нею}

Надзвичайно цінним $\epsilon$ висновок Михайла Бойченка про те, що перше покоління філософів освіти в Україні - з 1985 по 2004 рік - можна характеризувати як національних Пророків, а наступне, друге - з 2005 року перетворюється (згідно вимог інституційної перебудови) на національних Мандрівників [Бойченко 2019: 20]. Така постанова питання значно прояснює конотаційний смисл життєвих сценаріїв особистості, підпорядкованих трансформаціям соціальної сфери інформаційного суспільства, - створюючи адекватні сучасному суспільному становищу українських інтелектуалів денотати. Безперечно, в руслі поєднання традицій та інновацій у освітній діяльності як системі соціальних інститутів взаємопідтримки, вірно звучить і наступна настанова: «Вся поведінка людини у широкому сенсі слова $є$ запрограмованою: культурою в цілому, окремим соціальними системами, соціальними інститутами, ціннісними системами тощо. У тому числі людську поведінку програмує освіта неминуче і дуже глибоко. Водночас, у процесі соціалізації особистість не лише інтеріоризує зовнішні щодо неї соціальні норми, цінності і смислові коди, засвоює і використовує різноманітні технології поведінки, але завжди водночас вносить зміни у ці, спочатку зовнішні і незалежні від неї соціальні і культурні програми. Чим більш зрілою і самодостатньою у власних судженнях і поведінці стає особистість, тим більшою мірою вона може - а особливо, якщо сама цього хоче - здійснювати зворотній вплив на соціальні програми, аж до участі у створенні нових соціальних і культурних програм. Сфера освіти $\epsilon$ чи не найбільш благодатною для реалізації таких можливостей» [Бойченко 2019: 27]. Однак, у цьому твердженні приховано дві конотації - «зрілість» особистості і «бажання» особистості. Логічна пастка «замикання», «згортання» системи саморозвитку суспільства тут прихована у механізмі досягнення зрілості (відповідальності як ії складової) індивідами, які «не хочуть» вносити зміни, не збираються «дорослішати». Вже сучасне покоління дітей уяв- 
Алла Макарова. Архетипний характер освітньої діяльності особистості...

ляють собі спілкування виключно як комунікацію (для них природньою $\epsilon$ «постійна присутність у віртуальному просторі (А.M. - який наповнений цікавинками, далекими від «зрілих» наукових підходів), соціальних мережах (А.М. - в яких основним методом «самореалізації» $\epsilon$ непрофесійна, або й лексично ненормативна критика будь-чого, що потрапило до поля зору), активна презентація себе іншим (А.M. - переважно у формі візуальних фотообразів, які актуалізують реакцію схвалення чи негоції щодо тимчасового вигляду тіла, але не мають нічого спільного із особистістю) вже складають основу ідентичності сучасних дітей... така ситуація, звісно, породжує і певні негативні прояви - ігрову залежність, залежність від заохочення з віртуального світу, тролінг, булінг, кліпова свідомість тощо вже доволі широко досліджені не лише сучасними психологами і соціологами, але й філософами» [Бойченко 2019: 24]. Це і $\epsilon$ «зворотний бік» життя в інформаційному суспільстві, ціна безумовного прогресу технології при нерозвиненості особистості.

В цьому контексті оптимістична фраза про те, що «моделлю особистості в новій парадигмі освіти має стати інноваційна людина. Вона розглядає оточуючий світ не як сталу, гармонійну структуру, до якої потрібно пристосовуватися, а як сферу пізнавальної та практичної невизначеності, яку потрібно редукувати як послідовність різноманітних труднощів, що необхідно подолати. Винахідливість стає архетипом діяльності для інноваційної людини - а провідною метою навчання - формування в неї власної дослідницької позиції, тобто значення набуває процес переходу в освітній діяльності від школи пам'яті до інституту роботи з мисленням» [Предборська 2013: 23], конотує декілька невтішних для особистості смислів. По-перше, примусова фізична трансформація людини у дусі настанов трансгуманізму - кіборгізація. По-друге, хаотичність людської діяльності в дусі синергетичного підходу до реальності як такої, що «стається» випадково, несподівано, внаслідок дії не прораховуваної сукупності факторів, неконтрольовано індивідом. По-третє, самотність внаслідок постійної конкурентної боротьби «всіх проти всіх», в дусі лібералістських концепцій французького Просвітництва та волюнтаристсько-біологізаторських настанов XIX століття. По-четверте, втрата моральних меж, норм, принципів - у дусі прагматизму та егоїзму. I по-п'яте, «вузьколобість», обмеженість і світоглядне банкрутство в результаті («освіченість - це становлення людини як самостійної особистості, яка керується власним розумом та приймає власні рішення» [Міщенко 2015: 64]. Цей «комплекс» явно суперечить іншій декларативній настанові, яка на даний момент все ще вноситься у суспільну свідомість: «Саме гуманітарне знання безпосередньо впливає на формування духовності, світоглядно-ціннісні орієнтації, воно має використовуватися в розробці та реалізації політичних, економічних соціальних та 
інших програм. На його основі розробляються гуманітарні технології. До базових ідей гуманітарної освіти відносяться: 1. Філософія ідеї Людини як головної цінності життя; 2. Моральна відповідальність; 3. Загальнокультурна компетентність; 4. Діалог культур як засіб виховання; 5. Демократичність та толерантність» [Міщенко 2015: 62]. Все це просто не згадується у настановах типу: «Освіта у філософському вимірі - це, перш за все, «граничний» соціокультурний архетип. Його зміст утворює освоєння і привласнення наявних у суспільстві знань і навичок, щодо взаємодії людей з усім існуючим, щодо означень неіснуючого, а також створення й використання нової інформації про світ і нові навички дій у ньому». Акцентується саме інформаційний, а не ідейно-духовний аспект освіти, а згадка про те, що «освіта не стільки зорієнтована на трансляцію традицій, скільки сприяє тому, що нове покоління виробляє власні критерії поведінки в нових ситуаціях. Педагогічні інновації орієнтують інститути освіти на те, щоб готувати людину, здатну до постійної зміни навколишніх обставин, як і до зміни себе» [Савицька 2015: 88] вказує на безпідставність «постійного реформаторства» як безсистемного такого, що загрожує моментальним втрачанням набутого через трактування його як «застарілого». На нашу ж думку, крах, про який пише М.Бойченко, настане тоді, коли майбутнім поколінням не вдасться подолати логічну прірву між минулим та майбутнім освіти, і особистість опиниться у якості «транзитного пасажира» зі звичної «організації» у хаос «простору вільного вибору». Зауважимо, що «выбор является более качественным и безопасным для человека, если он имеет структурированное мировоззрение и истинные знания. Если же мировоззрение и жизненный опыт человека только находится в стадии формирования, то выбор у большинства случаев является ошибочным и часто опасным. В этом случае действительно качество мировоззрения влияет на качество поведения человека» [Будз 2016: 13].

\section{Потенціал архетипного підходу у вирішенні соціальних проблем сучасної освіти}

Несподіваним виходом із ситуації «соціальної транзитивності» являється звернення до концепції архетипів. На тлі «глобалізаційних» процесів (насправді, під їх прикриттям) актуалізуються у колективній підсвідомості найрізноманітніші, часом несподівані для свідомості, архетипи, що в своєму амбівалентному (контроверсійному, дихотомічному) прояві ілюструють всю іронічну глибину діалектичного підходу до явищ реальності, даючи підстави для критичного аналізу та осмислення. «3 позиції змісту архетипи розглядають як архаїчні образи та переживання, а з огляду на функціональне наповнення - як первісні форми 
Алла Макарова. Архетипний характер освітньої діяльності особистості...

адаптації людини в світі. Унікальність цієї концепції полягає в тому, що в такий спосіб відбувається збіг у житті індивіда бажаного, чуттєвого, емоційного, інтуїтивного, реально-стабільного та емоційного, що фактично $€$ підгрунтям для існування гармонії як внутрішньої, так і зовнішньої (людини зі світом)» [Шумейко 2017: 131]. Саме на розгляд функціональних соціальних аспектів освітньої діяльності ми звертаємо увагу у нашій статті, а архетипний підхід допоможе реалізувати мінімальну апологію традиційної освіти як форми «досвіду минулого» 3 тим, щоб забезпечити ї̈ перехід у «горизонти майбутнього».

Проблему складає те, що поняття «архетип», ставши надзвичайно популярним, вживається нині у найширших проекціях, включає найрізноманітніші нюанси. «Відтоді як швейцарський вчений К.Юнг 1919 р. у праці «Інстинкт та несвідоме» ввів до наукового обігу поняття психологічного архетипу, визначивши його як безособове або безпосередньо колективне несвідоме, осмислення цього феномену стало невід'ємним складником соціогуманітарних досліджень. У своїх працях на роль психологічного чинника звертали увагу П.Бурдьє, М.Вебер, Е.Дюркгейм, М.Еліаде, Г.Лебон, С.Московічі, Х.Ортега-і-Гассет, Г.Тард, Е.Фромм та ін. Архетип - це прихований у колективному несвідомому культурний стереотип, “першообраз", природжена психологічна схема мислення, яка опосередковано впливає на діяльність соціальних суб'єктів» [Сушій 2011: 64]. Отже, «архетип» може вказувати на соціальні якості, які мають бути реалізовані через «роль». Так, виводячи у своїй праці «Ігри, в які грають люди» образи Дитини, Родителя та Дорослого, Е. Берн обирає основою відмінності даних архетипів ступінь соціальної адаптованості індивіда до величезного поля факторів, що впливають на його життя, i звідси - ступінь обгрунтованості, розумності власних запитів щодо середовища [Берн, 2016]. Наше тлумачення архетипу в контексті даного дослідження спиратиметься на бернівську класифікацію, адаптуючи її психологічні «профілі» під специфіку початкової, середньої і середньої спеціальної та вищої освіти як рівнів розвитку не просто освіченості, а соціальної компетентності. Ми співвіднесемо ці рівні із двома архетипами, які виділені К.-Г.Юнгом як протилежні якості однієї особистості, iї світлу та темну сторони - «Персона» та «Тінь» [Юнг 1996], однак далі ми від юнгіанської архетипової класифікації абстрагуємося, більш того - модифікуємо смисл згаданих архетипів. «Персона» у нашій інтерпретації - проекція, сприятлива для соціально-орієнтованого розвитку, а «Тінь» - проекція, сприятлива для соцієтально-орієтованого розвитку. Тут ми враховуємо моделі, запропоновані Т.Плахтієм, як такі, які вважаємо репрезентативними [Плахтій 2014]. Вони якісно ілюструють процес координації особистісних архетипів через освіту і виховання. Надалі ми співставимо архетипи «Персони» та «Тіні» із 12-ти позиційною теорією 
архетипів [Марк \& Пірсон 2005], популярною у сфері брендингу, як найбільш чіткою у плані рольового позиціонування [Makarova 2020].

Серед тем, що можуть бути розкриті за допомогою такого аналізу освітньої діяльності - тема самопрезентації у проекції розрізнення соціального архетипу та соціальної ролі. Адже минуле саме по собі $\epsilon$ підставою оцінювати валідність актуальної самопрезентації як перспективнопотенційно дієвої. Те, чого особа вчиться у минулому, формує їі образ у майбутньому, а те, чого особа хоче від майбутнього, сформує образ іï думок і дій у теперішньому. Тому дуже важливо знати основні сценарії, за якими можна згрупувати певні діяльні комплекси під лаконічними назвами. На нашу думку саме ступінь відповідності самопрезентації набору якостей, зашифрованих у базовому архетипі конкретної особи $\epsilon$ основою правильного конструювання життєвого сценарію та виконання в подальшому відповідної ролі. Невідповідність же між якостями, закладеними внутрішнім сценарієм базового архетипу та сценарним малюнком зовнішньої ролі рано чи пізно призведе до викриття несправжності презентованої актуальної чи потенційної діяльності індивіда і перешкоджатиме його перетворенню на особистість через ціннісний дисонанс, хаос та зрештою провал сконструйованої «ширми».

\section{Змістово-функціональні зв’язки архетипу та освітньої діяльності}

За нашим переконанням, освіта архетипно створена як система впровадження у практику міжлюдських стосунків комплексу орієнтувальних, нормізуючих, інтеграційних дій (у проекції Персони), і захист від дезорієнтувальних, денормізуючих, дезінтегративних проявів діяльності (у проекції Тіні) методом поєднання навчання і виховання у єдиному двосторонньому (або багатосторонньому) процесі. Людська особистість розгортається у становленні місій спілкування з іншими людьми як реалізатор програми соціалізації, поступового переходу від стану Дитини до стану Дорослого - від Залежного до Повновладного. В межах масштабу своєї фізичної величини людина освоює маленький шматок простору і часу, в якому розгортає свою діяльність з реалізації місії освоєння як у-власнення середовища. Так з'являються ролі «голова сім'ї» (патріарх), «очільник наукової школи», «провідний спеціаліст» (авторитети, засновані на об'єктивному, сторонньому визнанні компетентності, зрілості, майстерності у виконанні місії), які і $є$ вершиною професійної самореалізації, базою подальшої «ситуації успіху» і всіх пов'язаних із самореалізацією конотацій [Рибалко 2016]. Але не навпаки. Без систематичної організації, мотивації, соціалізації, нормативізації, інтеграції як елементів освітньої діяльності саморозвиток, на нашу думку, немислимий. Дуже чесно в контексті «плинної сучасності», 
а не «плинного майбутнього», з якого невідомо чи вийдеш цілим, як влучно помічає Л. Бевзенко [Бевзенко 2017: 16-18], звучить констатація Л.Горбунової: «У цьому кочуванні соціальними різомами, просуваючись у невизначених просторах «між», ми опинилися наодинці з собою. Це означає, що тепер нам не відомі жодні межі самовдосконалення, окрім відсутності своїх власних здібностей, енергії, волі і рішучості. Бути сучасним стало означати нездатність зупинятися і тим більше стояти на місці. Бути сучасним означає постійно випереджати самого себе, перебувати в стані постійної непокори. Говорячи словами Ніцше, не можна бути людиною, не намагаючись бути надлюдиною. Це також означає мати індивідуальність, яка може існувати лише як відкритий, а тому нереалізований проект» [Горбунова 2017: 289].

Тому ми, за законами діалектичної амбівалентності архетипних життєвих сценаріїв, не можемо не визнати правоти констатації М.Бойченком «як поточного (Мандрівників доби національного Пробудження), так і наступного покоління (Героїв доби національного Спаду). I якщо наступні 5 років будуть завершальними для покоління Пробудження, то не можна не помітити і деяких явних ознак наближення доби національного Спаду в Україні» [Бойченко 2019: 23]. Надії, покладені сучасними інтелектуалами-Мандрівниками на своїх наступників-Героїв можуть, нажаль, не виправдатися, якщо архетип Героя реалізується у проекції Тіні, буде лише «воювати», але не «створювати». Культурний Герой як Діяч здатний повністю зламати кордони звичної ментальної матриці, здійснивши революцію у свідомості, але нездатен без поєднання із архетипом Мудреця як проекції Персони дати собі раду із наслідками власного руйнування «застарілих меж». В історії соціології вже були приклади наукових революцій, здійснені такого типу Героями, наприклад, О. Контом, який вважав за правильне і потрібне «вирізати» з гуманітарного знання абстрактні метафізичні міркування, які не дають математичної конкретності. Практично одразу ж по появі такого «героїчного маніфесту» тодішні Мудреці розпочали дискурс з відновлення розірваної павутини гуманітарних смислів, запропонувавши альтернативні інтегруючі підходи (Е. Дюркгайм, М. Вебер, П. Сорокін). Проте, чи стане Духу у Мудреців майбутнього зупинити Героя-Тінь на шляху руйнувань, буквально «пощадивши філософію» ще раз - це дійсно, «найважче питання». Класичним сценарієм становлення особи з архетипною схильністю Володаря як не лише «завойовника просторів», а й як Культурного Героя («розширювача просторів»] [Ковтун 2008] є сценарій його навчання і виховання (педагогічного супроводу) Мудрецем - вчителем, гуру, наставником. В цьому плані достатньо є згадати тандем Аристотеля та Олександра Македонського; антитетичною, реалізованою за сценарієм Тіні, $\epsilon$ схема самоствердження Калігули у творі А. Камю, який відзначався впертістю у власній позиції 
і фізично знищував своїх радників та друзів, деградувавши у підсумку від стану Самотнього Героя до стану спочатку Бунтаря (підліткова ментальна матриця), а потім Блазня (ментальна матриця жорстокої дитини), втративши до-рослу велич Володаря у очах підданих. Такий Герой спирається у своїй діяльності передусім на Ідею, не турбуючись про критичний аналіз наслідків при ії прямому втіленні - він стає фігурою, що виконує завдання цієї Ідеї, її механічним придатком, простим виконавцем, рабом. Свідомість, замкнена на собі, енергетично повноцінна завдяки домінанті волі над душею, нагадує батарейку, що живить атомну зброю - при невеликому масштабі енергоносія втрати від руйнувань завдяки ії діяльності бувають катастрофічно великими (принцип Гітлера). Якщо доросле покоління Пророків, що вже деградувало до стану Мандрівників (безхатченків), дозволить само-вільний розвиток наступного покоління в алгоритмах спілкування виключно з неживим, без альтернативи спілкування з живим, то навряд чи слід чекати позитивних соціальних та суспільних сценаріїв у виконанні поколінь, щодо яких М. Бойченко влучно відмітив: «у теорії XYZ відсутня буквенна назва для повоєнного покоління, тоді як наступні має свій чіткий означник - покоління «х», «у», «Z», адже «бебібумери» ще дотримуються якихось канонів, шанують традиційні інститути, тоді як наступні покоління позначено як математичні змінні, під які можна підвести дуже різні значення (A.M. - iдеї!), а об'єднувати можна лише доволі умовно» [Бойченко 2019: 16]. Все це вказує на те, що «пайдейя $\epsilon$ підготовкою людини до щасливого і успішного життя у суспільстві, головним чином - через сприяння її адекватної самоідентифікації з власним поколінням», як висновує М. Бойченко, і здійснювати цю пайдейю повинні не «стейкхолдери», які щойно стали на шлях самоосвіти та самопрезентації (за допомогою довільно обраних «освітніх продуктів» чи «освітніх пропозицій» у вигляді мемів, пупів, RUTP та інших карикатур на культуру), а досвічені провідники, які здатні дійсно інтегрувати накопичений попередниками досвід і у лаконічній, легкій для сприйняття формі передати цей досвід майбутнім поколінням. Тільки так вдасться, на нашу думку, уникнути в майбутній соціальній та суспільній діяльності ефекту колективного дитячого «стрибання на батуті», під яким - порожнеча, i смислом якого $\epsilon$ «політ фантазії», але не «грунтовність».

Дуже правильно, з огляду на це, що інструментами соціальної «організації хаосу у систематичну діяльність» стосовно освіти є класична система освітніх рівнів (рівнів акредитації), яка в Україні представлена ланками: дошкільної освіти; початкової загальної освіти; базової загальної середньої освіти; повної загальної середньої освіти; професійно-технічної освіти; вищої освіти. На наш власний погляд, архетипи як акумулятори і репрезентанти соціальної пам'яті та соціального досвіду (традицій, норм, цінностей, ідентичностей і т.п.) виконують як мінімум 
Алла Макарова. Архетипний характер освітньої діяльності особистості...

три функції, що безпосередньо корелюють із функціями освіти. Спочатку представимо цю кореляцію як систему взаємовідношень смислових рівнів початкової, середньої і середньої спеціальної та вищої освіти, і коротко розкриємо зміст соціальних функцій архетипу на кожному 3 рівнів.

Поняття «рівень освіти», на нашу думку, визначає сукупність освітніх завдань, які відповідають можливостям певного вікового періоду та соціалізаційним навичкам, які необхідно опанувати в цьому періоді. Вікова психологія пропонує як варіант підходу поділ провідної діяльності на «гру», «навчання», «працю». На наш погляд, архетипно-функціональний вимір є точнішим корелятом смислів, вимог та ефектів впливу освіти на розвиток особистості.

\begin{tabular}{|c|c|c|c|c|}
\hline $\begin{array}{l}\text { Рівень освіти } \\
\text { (орієнтація на якості } \\
\text { особи - її провідну } \\
\text { діяльність, емоційні ха- } \\
\text { рактеристики, соціальні } \\
\text { потреби розвитку, межі } \\
\text { можливостей, і нахили) }\end{array}$ & \multicolumn{4}{|c|}{ Архетипна складова / Архетипна функція } \\
\hline \multirow{2}{*}{$\begin{array}{l}\text { Початкова освіта } \\
\text { (орієнтація на якості } \\
\text { Дитини) - Маг, Творець } \\
\text { (проекція Персони), } \\
\text { Простак, Блазень (про- } \\
\text { екція Тіні) }\end{array}$} & \multicolumn{4}{|c|}{ Орієнтувально-координаційна складова } \\
\hline & $\begin{array}{l}\text { Організаційна та } \\
\text { дезорганізаційна } \\
\text { функції - опану- } \\
\text { вання порядку } \\
\text { (хаосу) }\end{array}$ & \multicolumn{2}{|c|}{\begin{tabular}{|l} 
Мотиваційна та \\
демотиваційна \\
функції - форму- \\
вання мети (цілей, \\
смислів) \\
\end{tabular}} & $\begin{array}{l}\text { Соціалізаційна та } \\
\text { десоціалізаційна } \\
\text { функції - вибір } \\
\text { зразків (антизразків } \\
\text { для поведінки) } \\
\end{array}$ \\
\hline \multirow[b]{2}{*}{$\begin{array}{l}\text { Середня та середня } \\
\text { спеціальна освіта } \\
\text { (орієнтація на якості } \\
\text { Родителя) - Славний } \\
\text { малий, Коханець (про- } \\
\text { екція Персони), Шукач, } \\
\text { Бунтар (проекція Тіні) }\end{array}$} & \multicolumn{4}{|c|}{ Стереотипізуюче-нормативна складова } \\
\hline & $\begin{array}{l}\text { Гендерна стерео } \\
\text { типізація та дес- } \\
\text { тереотипізація - } \\
\text { розуміння основ } \\
\text { статевих ролей } \\
\text { (відносин) }\end{array}$ & \multicolumn{2}{|c|}{$\begin{array}{l}\text { Вікова стерео типі- } \\
\text { зація та дестерео- } \\
\text { типізація - розумін- } \\
\text { ня основ традицій, } \\
\text { поколінь }\end{array}$} & $\begin{array}{l}\text { Статусна стеретипі- } \\
\text { зація та дестерети- } \\
\text { пізація - організація } \\
\text { пошуків професійної } \\
\text { самоідентифікації }\end{array}$ \\
\hline \multirow{2}{*}{$\begin{array}{l}\text { Вища освіта } \\
\text { (орієнтація на якості } \\
\text { Дорослого) - Дбайли- } \\
\text { вий, Мудрець (проекція } \\
\text { Персони), Герой, Воло- } \\
\text { дар (проекція Тіні) }\end{array}$} & \multicolumn{4}{|c|}{ Інтеграційно-систематизуюча складова } \\
\hline & \multicolumn{2}{|c|}{$\begin{array}{l}\text { Внутрішньо-інтеграційна } \\
\text { функція - систематизація } \\
\text { знань про себе, самоорганіза- } \\
\text { ція }\end{array}$} & \multicolumn{2}{|c|}{$\begin{array}{l}\text { Зовнішньо-інтеграційна } \\
\text { функція - організація власної } \\
\text { діяльності, самопрезентація та } \\
\text { зміна світу }\end{array}$} \\
\hline
\end{tabular}

Саме тому ми пропонуємо уважно поглянути на функції освітньої діяльності в контексті архетипного підходу, пропонуючи їх трикомпонентну систему в якості базової. Ілюструючи даний механізм, зупинимося на важливості правильної ідентифікації архетипно-рольового комплексу особистості в контексті проблеми її самопрезентації, в тому 
числі в контексті освітньої діяльності. Наша тема вимагає виявити ролі та архетипи, пов'язані із завданнями освіти, педагогіки як системи соціально-психологічних сценаріїв, в яких індивід, обираючи роль Вчителя, повинен, на нашу думку, втілювати певні архетипні якості [Кравченко 2013]. Адже якщо роль - це вистава для Іншого, то можна говорити про «розігрування ролі Вчителя» не менше, ніж про «розігрування ролі» Мага, Творця, Мудреця, Славного малого, Дбайливого, Героя, Володаря. Однак всі ці проекції особистісного змісту насправді мають внутрішньопсихологічне спрямування, виявляють налаштування свідомості або підсвідомості, і у зовнішньому, соціальному житті не мають адекватного рольового виразу, - позбавлені конкретного сценарію. Для ролі повинні бути чітко окреслені соціально-ідеологічні декорації, зрозумілі за параметрами набору «функцій», і кожна роль, виявляючись через діалог, несе передусім чітку функцію для Іншого. Такою соціальною функцією в суспільній системі $\epsilon$ професія або ж система світоглядно-ідеологічних переконань. Професії можна навчитись, засвоївши ії функції, тобто ідею ролі; ідеологію можна змінити. Архетип же діє сам по собі, проявляючись спонтанно, збагачуючи носія певними якостями, несвідомо присутніми як ідея особистості, не підвладний засвоєнню на рівні «знання - уміння - навички». Якщо роль представляє нам набір схем діяльності (зовнішній вираз), то архетип - набір підстав діяльності (внутрішній мотив).

Що ж важливіше - роль чи архетип? Що у самопрезентації особи має бути акцентовано? Адже, з одного боку, змушувати особу грати роль це робити ії психологічно неповноцінною; з іншого ж - залишити її на рівні власного архетипу - значить відмовити у структурному, соціальному зростанні, трансформації, досягненні рівня особистості. Проте чи можливе взагалі моральне формування особистості, якщо ії внутрішній образ, архетип суперечить зовнішнім нав'язаним, штучно сконструйованим ролям? I чи слід ставити такі завдання? Можливо, слід виявити той з внутрішніх архетипів особи, який найбільш соціалізований, i підкріплювати його, давати особі мотивацію до самопрезентації саме у цій ролі, а не в іншій, соціалізувати ï на основі конструктивних, а не деструктивних для суспільства якостей. Якості ж відверто деструктивні сублімувати за допомогою тих видів діяльності, де вони будуть доцільними.

Сучасна превентивна освіта, базована на компетентнісному підході, дає широкі можливості проявити і сформувати якості особи. Проявити - означає «виявити, щоб запобігти»; сформувати - означає «дати базу для розвитку». В такій якості сучасна освіта претендує на роль «просвіти», а не простого «інформування», проте, на нашу думку, для реалізації цих завдань повинна не просто шукати нові методи зовнішнього 
реформування освітньої діяльності, а включати в себе такі функції, як кореляційна, корекційна та компенсаційна, базовані на чіткому усвідомленні результату а) виявлення архетипової схильності та її рольового еквіваленту; б) заохочення актуальної конструктивної архетипової схильності та реалізації вищих рівнів розвитку її рольового еквіваленту; в) пропозиції альтернативного до наявної деструктивної архетипової схильності рольового еквіваленту, підборі та активізації перспективної соціальної ролі, що корелює з елементами наявної архетипової схильності. У разі якісного виконання цих функцій реалізуються завдання виховання розвиненої особистості, чиї компетентності враховують розуміння власної сутності та можливості свідомого моделювання власної поведінки у майбутньому на основі зв'язку минулого та теперішнього.

Кореляційна функція (завдання) освіти - виявити співвідношення між архетипом і роллю у самопрезентації учня, тобто допомогти учневі «пізнати самого себе». Адже далеко не завжди соціально конструктивна роль відповідає конструктивному архетипу, і навпаки, і чим швидче виявиться невідповідність, тим більше буде шансів змінити життєвий сценарій. Цікаві і часом небезпечні комбінації дають поєднання ролі Сім'янина та архетипу Правдошукача, ролі Законодавця та архетипу Тюхтія, ролі Християнина та архетипу Руйнівника і т.д. Так, особа з соціальними нахилами Злочинця (Хулігана) може мати внутрішній архетип Творця або Організатора, і таким чином отримує підставу для переорієнтації своєї потенційної діяльності з соціально деструктивної на соціально конструктивну, зміну небезпечної ролі в подальшому. Ця підстава, закладена у минулому, тобто в історії діяльності особи, може бути виявлена освітніми засобами на рівні діагностики, як факт, наявність на цей момент, - матеріал, що дає простір для творчого соціального конструювання. Працюючи з минулим особи, Вчитель виявляє потенцію до перетворення теперішнього і майбутнього, які без здійснення кореляційної функції (завдання) автоматично відтворюють некоректну самопрезентацію і заперечують можливість розвитку особи. Фактично Вчитель зосереджується на реалізації архетипу Організатора, упорядковуючи знання учня про самого себе, виступаючи в ролі певного менеджера з самопізнання.

Звідси, другим кроком, після виявлення специфіки самопрезентації, як встановлення діагнозу відповідності, валідності архетиповій сутності, повинен бути реалізований ряд заходів із виправлення, збалансування діяльності шляхом зміни соціальної ролі. Саме освіта володіє системою прийомів і засобів, що дозволяють здійснити корекційну функцію щодо самопрезентації індивіда і виконати завдання збалансування їі компонентів у теперішньому. Корекційна функція (завдання) освіти 
полягає у підборі в акції, а не в потенції, системи ролей, які якісно реалізуватимуть позитивні сторони архетипу, а не пригнічуватимуть його. Фактично вчителем реалізується архетип Хранителя, який витягає наявні, але приховані якості учня і ставить їх на перше, пріоритетне місце, висвітлюючи таким чином

Проте, зупинка на даних двох кроках створює якість роботи Вчителя з так званими «обдарованими» дітьми, відносячи всіх інших до категорії «необдарованих», що суперечить гуманістичному та особистісному підходам у педагогіці. Виявити або прищепити обдарованість, працювати на, нехай і механічне, нав'язування зразків - неодмінне завдання педагогіки. Тут вже можна говорити про дієвість інформування про бажану поведінку, соціально схвальні ролі, зразки, сценарії. Фактично, на цьому етапі починається програвання Вчителем архетипу Відтворювача, репродуктора; проте, без збереження орієнтації на архетип Творця ця діяльність приречена на провал; просте спостереження за реалізацією в теперішньому заданих минулим архетипових сценаріїв не здатне змінити майбутнє, компенсувати нестачу позитивних якостей. Компенсаційна функція (завдання) освіти - доповнити нестачу якостей через творчий підхід до особистості, запропонувати вихід із ситуації замкненості у своїй архетиповій природженості шляхом моделювання якостей, гри «в іншого». Наприклад, архетип Руйнівника, що є основою соціальної ролі Хулігана в шкільні роки, без творчого виконання Вчителем компенсаційного завдання у школі, переростає в дорослому житті у роль Злочинця; якщо ж Вчитель у школі вчасно надасть можливість «програти» альтернативну архетипову модель Хранителя (Захисника), то в майбутньому індивід зможе якісно виконувати соціально схвальну роль Воїна тощо.

Отже, справжнє виконання ролі Вчителя починається не з самопрезентації і навіть не з самоосвіти, а з підвищення самоусвідомлення Вчителя як виразника архетипів, а якщо самопрезентації та саморозвитку - то не «в ролі», а «в якості» корелятора, коректора і компенсатора розвитку - як соціального, так і психологічного планів. В загальному як рекомендацію щодо майбутнього освітянської діяльності можна підтримати лаконічну конотацію: «Центральною постаттю освітнього процесу є викладач, який керує та направляє учня, тому основою педагогічної майстерності є особистість викладача, його творчий потенціал та культурний рівень» [Міщенко 2015: 61].

На основі всього вищевикладеного, пропонуємо авторську схему співвідношення соціальних функцій архетипу та завдань і функцій освіти: 
Алла Макарова. Архетипний характер освітньої діяльності особистості...

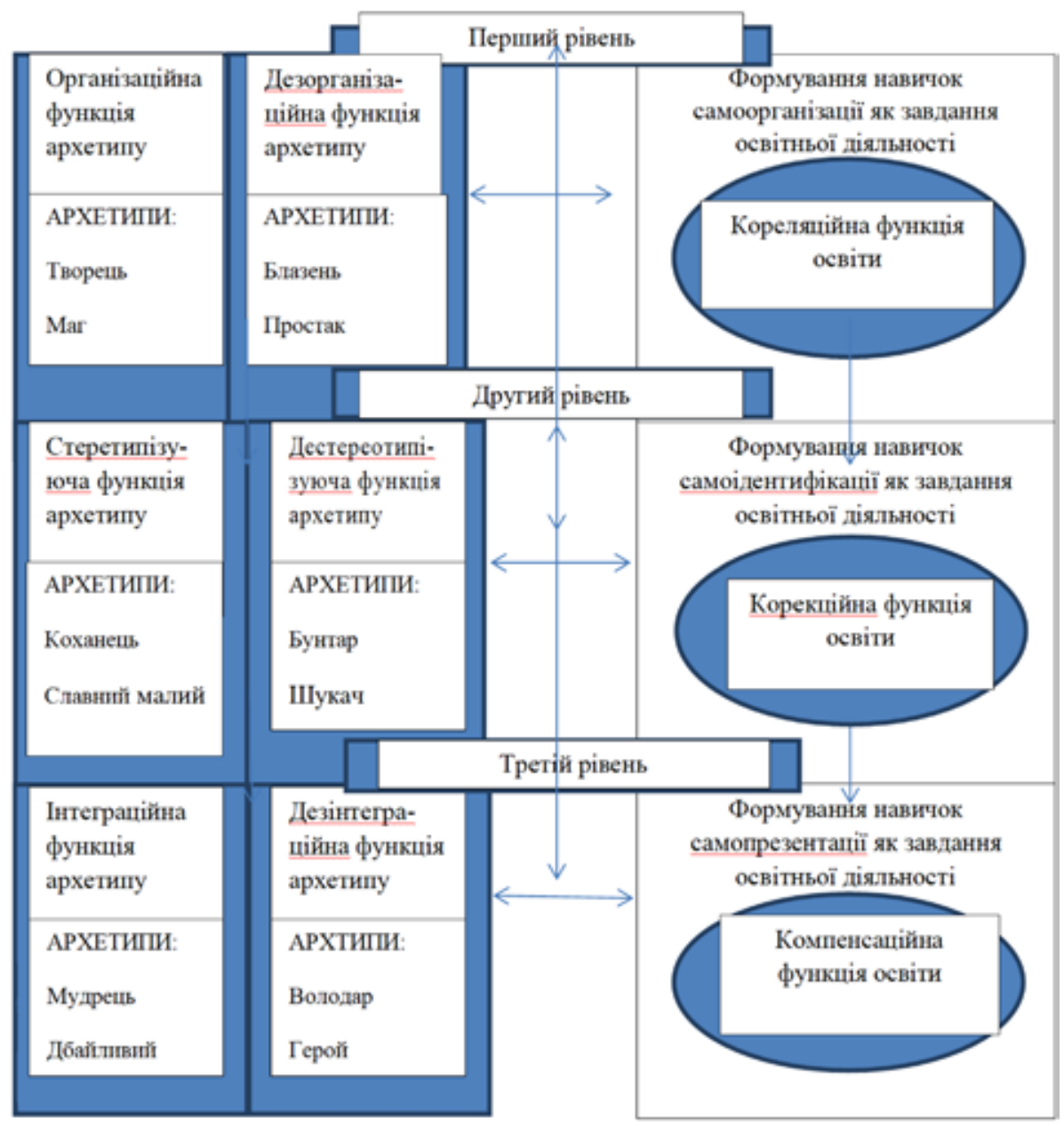

\section{Архетипні проекції ролі Вчителя в освітній діяльності}

Таким чином, ми бачимо, що реалізуючи комплекс завдань кореляції, корекції та компенсації щодо збалансованого співвідношення «роль» «архетип» у свідомій самопрезентації учня, Вчитель починає діяти як Провідник, а не лише як Проповідник. Адже «вчитися - не значить певним чином поповнювати багаж знань, озброюватись корисною для подальшого життя інформацією, а вирушати в путь, протягом якого наші справи і вчинки (тобто усе наше єство, а не просто свідомість, інтелект) приводяться у відповідність. 3 чим? - А з тим, що до нас “у тому чи іншому випадку звернене по істині". Тобто, приводити себе у відповідність не просто з чимось зовнішнім, покладеним перед нами, а з таким чимось 
дивним, загадковим, що мало того, якось звернене до нас, звертається до нас, але ще й здійснює це “по істині", за своєю істиною» [Возняк \& Возняк 2011: 47]. У освітній (зокрема, педагогічній) діяльності така орієнтація означає турботу про те, щоб особистісні нахили здобувачів освіти співпадали із професійними пропозиціями, які надає суспільство, тобто до максимальної інтеграції окремої людини у систему спільної творчо продуктивної суспільної діяльності. Українська культура органічно (архетипно) сприятлива для розвитку таких функцій освіти, які несуть в собі конотації просвітництва, провідництва (супроводу), підтримки, розкриття позитивних (конструктивних) та корекцію негативних (деструктивних) схильностей конкретної особистості.

\section{Висновки}

Стосовно ж реалізації мети нашої статті - виявити стійкі функції, принципи, елементи, які при будь-якому реформуванні освітня сфера, зокрема, педагогічна, в жодному разі не повинна втрачати, які повинні бути збереженими при будь-якій системі освіти - то ми виділимо в її підсумку як мінімум шість гуманітарних завдань освіти на «сьогодні, завтра і завжди» в якості її архетипної основи:

- По-перше, це архетип неперервності освіти.

- По-друге, архетип єдності навчання і виховання.

- По-третє, архетип формування світогляду через освіту.

- По-четверте, архетип передачі досвіду через освіту.

- По-п’яте, архетип соціального супроводу освітньо-виховного процесу.

- По-шосте, архетип формування моральних якостей особистості через освіту.

\section{Посилання:}

Бевзенко, Л. (2017). Передмова. Кочубей Н., Нестерова М. (ред.). Людина в складному світі. Суми: Університетська книга, 7-16.

Берн, Э. (2016). Игры, в которые играют люди / пер. с англ. А. И. Фет. Nyköping: Philosophical arkhiv.

Бойченко, М. (2019). Завдання для філософії освіти в Україні у світлі теорії поколінь. Філософія освіти, 25(2), 8-34. https://doi.org/10.31874/2309-1606-2019-25-2-1.

Будз, В., Гоян, И. (2016). Мировоззренческие факторы мотивации человеческой деятельности. Социальное воспитание, (2), 10-17.

Возняк, В. \& Возняк, С. (2011). Зміст поняття «навчання» у філософії М. Гайдегґера. Культурологічна думка, (4), 46-51.

Горбунова, Л. (2017). Трансформативне навчання: стратегія самоорганізації індивіда в контексті складності сучасного світу. Кочубей Н., Нестерова М. (ред.). Людина в складному світі. Суми. Університетська книга, 286-321.

Ковтун, Н. (2007). Архетип культурного героя в українській духовній традицї: історико-філософський контекст: Автореферат дисертації на здобуття наукового 
ступеня кандидата філософських наук за спеціальністю 09.00.05. - історія філософії. Київський національний університет імені Тараса Шевченка. Київ.

Кравченко, А. (2013) Архетип учителя: ідея, образ, відповідальність. Львів: Вид-во «Ліга-Прес».

Марк М., \& Пирсон, К. (2005). Герой и бунтарь. Создание бренда с помощью архетипов / пер. с англ. под ред. В. Домнина, А. Сухенко. Санкт-Петербург: Питер.

Міщенко, М. (2015). Освітній процес та взаємовідносини викладача та учня в межах сучасної філософії освіти. Гуманітарний вісник Запорізької державної інженерної академії, (61), 60-66. doi: http:// dx.doi.org/10.30839/2072-7941.

Плахтій, Т. (2014). Архетипне управління соціальними системами та організаційні інструменти для його реалізації. Незалежний культурологічний часопис Ï. http:// ji-magazine.lviv.ua/anons2014/Plachtij_Archetypne_upravlinnya.htm.

Предборська, І., Вишинська, Г., Гайденко, В., Гамрецька, Г., \& Савчук, Н. (2013). Філософські абриси сучасної освіти. Суми. Університетська книга.

Рибалко, Л., \& Куценко, Т. (2016). Професійна самореалізація учителів загальноосвітніх навчальних закладів в умовах сучасних викликів (акмеологічний аспект). Огнев'юк В., Сисоєва С., Фруктова Я. (ред.). Сучасні акмеологічні дослідження: теоретико-методологічні та прикладні аспекти : Монографія. Київ: Київський університет ім. Б. Грінченка, 684-715.

Савицька, I. (2015). Філософські аспекти модернізації освіти в контексті традицій та інновацій. Науковий вісник Національного університету біоресурсів і природокористування України. Серія: Гуманітарні студіï, (228), 85-90.

Сушій, 0. (2011). Міждисциплінарні дослідження державного управління: архетипний напрям. Вісник Національної академії державного управління при Президентові України. 3. 52-71.

Шумейко, О. (2017). Дихотомія концептів інституту сучасної сім'ї як реакція на кризу ідей епохи модерну. Філософські та методологічні проблеми права, 1 (13). 129-137.

Юнг, К.-Г. (1996). Душа и миф: шесть архетипов / пер. с англ. В. В. Наукманова под общей редакцией А. А. Юдина. Киев: Государственная библиотека литературы для юношества.

Makarova, A. (2020). Archetypal approach to activity: legitimation by practice. Skhid. $1(65), 75-81$.

\section{References:}

Bevzenko, L. (2017). Preface. Kochubey N., Nesterova M. (Ed.). Human in Complexity. Sumy: University Book. [In Ukrainian].

Berne, E. (2016). Games that people play / transl. from English. Nyköping: Philosophical arkhiv. [In Russian].

Boichenko, M. (2019). Tasks for Philosophy of Education in Ukraine in the light of the Theory of Generations. Philosophy of Education. 25(2), 8-33. [In Ukrainian].

Budz, V., Goyan, I. (2016). Worldview factors of motivating human activity. Social Education, (2), 10-17. [In Russian].

Wozniak, V., \& Wozniak S. (2011). The meaning of the concept of "learning" in the philosophy of M. Heidegger. Culturological thought, (4), 46-51. [In Ukrainian]. 
Gorbunova, L. (2017). Transformative learning: the strategy of self-organization of individual in the context of complexity modern world. Kochubey N., Nesterova M. (Ed.). Human in Complexity. Sumy: University Book, 286-321. [In Ukrainian].

Kovtun, N. (2008). Archetype of the cultural hero in Ukrainian spiritual tradition: historical-philosophical context. Manuscript. Dissertation for obtaining the scientific degree of the Candidate of Science in Philosophy: 09.00.05. - History of Philosophy. Taras Shevchenko Kyiv National University. Kyiv. [In Ukrainian].

Kravchenko, A. (2013). Teacher archetype: idea, image, responsibility. Liga-Press, Lviv. [In Ukrainian].

Mark, M. \& Pearson, K. (2005). Hero and Rebel. St. Peterburg: Peter, 336. [In Russian].

Mishchenko, M. (2015). Education process and relations of teacher and student within the framework of Modern Philosophy of Education. Humanities bulletin of Zaporizhzhe State Engineering Academ. Vip. 60, 60-66. [In Ukrainian].

Plakhtiy, T. (2014). Archetypal management of social systems and organizational tools for its implementation. Independent culturological journal YI. URL: http://ji-magazine. lviv.ua/anons2014/Plachtij_Archetypne_upravlinnya.htm - (accessed 26.07.2020) [In Ukrainian].

Predborska, I., Vyshinska, G., Gaidenko, V., Gamretska, G., \& Savchuk, N. (2013) Philosophical outlines of modern education. Monograph. Sumy. University book. [In Ukrainian].

Rybalko, L., \& Kutsenko, T. (2016) Professional self-realization of teachers of secondary schools in the conditions of modern challenges (acmeological aspect). Ognevyuk, V., Sysoeva,S., Fruktova, J. (Ed.). Modern acmeological research: theoretical and methodological and applied aspects: monograph. Kiev: Borys Hrinchenko Kiev University, 684-715. [In Ukrainian].

Savytska, I. (2015). Philosophical aspects of modernization of education in the context of traditions and innovations. Scientific Bulletin of the National University of Life and Environmental Sciences of Ukraine: [collection. Science. etc.]. Kiev. Series, Humanities Studies Vol. 228. Scientific journal of national university of life and environmental sciences of Ukraine. Series: Humanitarian Studies, 85-90. [In Ukrainian].

Sushiy, 0. (2011). Interdisciplinary research of public administration: archetypal direction. Bulletin of the National Academy of Public Administration under the President of Ukraine, (3), 52-71. [In Ukrainian].

Shumeiko, O. (2017). The Dichotomy Concepts of Family Institute as a Reaction to the Crisis of Modern Epoch Ideas. Philosophical and methodological problems of law, 1 (13), 129-137. [In Ukrainian].

Yung, K-G. (1996). Soul and Myth: Six Archetypes / transl. from English. Kyiv: State Library for Literature for Adolescence.[In Russian].

\section{Alla Makarova. The archetypal character of the educational activity of person: socio-philosophical analysis}

The article analyzes the problems of modern educational activities in the context of the socio-philosophical analysis of the specifics of the information society. The problems of "self-development" and "self-presentation" of a personality are raised in the context of their interpretation in the context of the current situation of social transitivity. The position of eliminating educational institutions from educational processes, the threat of creating the phenomenon of education without a pedagogical component is considered as problematic. 
The "traditional" and "innovative" accents in the socio-philosophical discourse of education are compared, their semantic connotations are presented. The necessity of maintaining the balance of archetypal-educational functionality is substantiated, which consists in the formation of a system of socialization actions through a complex of educational levels, which have archetypal meaning expressed by special functions. The scientific novelty of the research is the schematic comparison of the functional characteristics of the archetype with the tasks of different levels of education as an orientation towards different potencies of the personality. In particular, the social functions of archetypes (in the author's three-component concept), the archetypal typology and schematics of E. Berne, C.-G. Jung and M. Mark and M. Pearson were compared with the tasks and meanings of the levels of education (primary, secondary and secondary special, higher), there are three functions of education, closely determined by the archetypal meanings of pedagogical activity. At the same time, a scheme is proposed in which the orientational-coordinating, stereotyping-normative and integrative-systematizing archetypal components form the tasks and functions of education: correlation, correctional and compensatory. The purpose of the article is to identify stable functions, principles, elements that, in any reform of the educational sphere, in particular, pedagogical, should be preserved, since they constitute the semantic foundations of its existence as a social institution of personality development. These are recognized as the unity of training and education, the unity of the past, present and future as organic links in the transfer of social experience and the preservation of social memory. Accordingly, six archetypes of educational activities are identified.

Key words: archetype, educational activity of personality, socio-philosophical analysis, information society, social role.

Алла Макарова - кандидат філософських наук, доцент, докторант кафедри філософії та політології Житомирського державного університету імені Івана Франка.

E-mail: makarova_ao@ukr.net

https://orcid.org/0000-0001-7270-0135

Alla Makarova - Ph. D., Associate Professor, Doctoral Student at the Department of Philosophy and Political Science Zhytomyr Ivan Franko State University.

E-mail: makarova_ao@ukr.net

https://orcid.org/0000-00001-7270-0135 